\title{
Standard of residency in Poland and selected European countries: Comparative analysis
}

\author{
Paweł Ulman
}

\begin{abstract}
A B S T R A C T
Objective: The aim of the paper is to present the standard of residency in the European Union countries, in particular against the background of the housing policy implemented in selected EU countries.

Research Design \& Methods: Linear ordering and hierarchical cluster methods were used for statistical comparative analysis of studied countries. The data on the surroundings of the home and the financial capacity of respondents to maintain the home are taken into account. The data were taken from EQLS (European Quality of Life Survey) the 4th-edition survey was held in 2016 and 2017.
\end{abstract}

Findings: The article shows significant differences in the standard of residency among European countries. In separate areas for assessing the housing situation, no country ranked first in all areas at the same time. In some cases, the position of a given country (e.g. Finland) is fundamentally different due to the considered area of standard of residency assessment. In terms of a multidimensional assessment of this standard, Poland is generally better rated than using commonly used housing situation indicators (e.g. the number of rooms per person).

Contribution \& Value Added: An added value is the proposal to measure the housing situation of the population not only on the basis of measuring one or two indicators, but in a multidimensional approach with separate areas of assessment. This allows for a broader and deeper look at the problem of satisfying one of the basic human needs of living.

\begin{tabular}{|c|c|}
\hline Article type: & research paper \\
\hline Keywords: & $\begin{array}{l}\text { social and economic policy; housing; quality of life; statistics; linear } \\
\text { ordering; hierarchical clustering }\end{array}$ \\
\hline JEL codes: & $\mathrm{I} 1 \mathrm{1}, \mathrm{R} 21, \mathrm{R} 23, \mathrm{R} 28$ \\
\hline
\end{tabular}

\section{Suggested citation:}

Ulman, P. (2019). Standard of residency in Poland and selected European countries: Comparative analysis. International Entrepreneurship Review (previously published as International Entrepreneurship / Przedsiębiorczość Międzynarodowa), 5(4), 59-75. https://doi.org/10.15678/IER.2019.0504.04 


\section{INTRODUCTION}

Housing is a type of good, whose possession (ownership or rental) is one of the basic human needs; on the other hand, it is the foundation for satisfying other basic needs and higher-order needs defined in the classification proposed by A. Maslow. At the same time, having a home of a sufficiently high standard is often an indicator of the affluence of a given household and thus forms the basis for determining its economic situation, which in turn is used for studying poverty of households (population). The housing situation of a given individual is an important area for determining whether the individual is at risk of poverty or not (Kwarciński \& Ulman, 2018; Soltes \& Ulman, 2015).

The need for housing is not only an individual need of the individual members of society in a given country. Because of its universality, it has a social dimension, which means that the state should be more or less involved in the process of satisfying the need for housing by formulating and implementing appropriate housing policies. In developed countries, such policies are implemented, although they may vary according to the scope and tools used. In case of selected European Union countries, a synthetic description of the applied solutions can be found in the (Wójciaczyk, 2016). Moreover, the situation on the housing market and current housing policy solutions in European Union member states are presented in publications from the series entitled A Housing Europe Review (Pittini, Koessl, Dijol, Lakatos \& Ghekiere, 2017).

The abovementioned actions of the state have their basis, justification and obligation in international and national law of the individual states. Article 25 of the 1948 Universal Declaration of Human Rights states that everyone has the right to a standard of living adequate to ensure the health and well-being of him/herself and their family, including, inter alia, housing. Mothers and children are to be given special protection. Article 31 of the revised European Social Charter contains a provision obliging the signatory states to ensure effective exercise of the right to housing by means of: supporting access to housing at an appropriate level, prevention, reduction and further elimination of homelessness, increase in income-based availability of housing. The European Union does not formally shape the housing policy of the member states, but it pays particular attention to combating social exclusion and poverty. This problem is highlighted in one of the five points of the Europe 2020 strategy (Salomon \& Muzioł-Węcławowicz, 2015). Undoubtedly, owning a home and its standard are key elements influencing social exclusion and indicating the level and quality of life of individual members of society.

The aim of the paper is to present the standard of residency in the European Union countries, in particular against the background of the housing policy implemented in selected EU countries. Since decent housing conditions can be understood more broadly not only as the physical condition of the dwelling, but also as its surroundings, apart from parameters relating to the condition of the dwelling, data on the surroundings of the home and the financial capacity of respondents to maintain the home are taken into account in the multidimensional perspective. The data were taken from EQLS (European Quality of Life Survey) - the 4th-edition survey was held in 2016 and 2017. The comparison of countries was made using linear and hierarchical clustering ordering methods. 


\section{LITERATURE REVIEW}

\section{Housing needs}

The dictionary definition of the concept of a need is reduced to the statement that it is what is necessary for normal existence or proper functioning. It can be said that the need is a lack, which is defined as a shortage of certain objects or satisfaction (Wiśniewski \& Śleszyński, 1976). Based on this notion, it could be assumed that housing needs are a lack of housing or a lack of adequate housing for the person(s) concerned (Seling, Milligan, Phibbs, \& Thompson, 2008).

However, the problem of defining housing needs is not that simple, as it is difficult to clearly state what a need is in general terms. Does it differ from such notions as aspiration, wants, desire, choice or guaranteed right to own or receive something (a home)? Moreover, it is not clear whether needs are considered universal, objective and absolute or whether they are relative, subjective and culturally specific. Researchers studying the problem have divided into three camps: those who claim that needs are necessarily relative; those who consider needs to be absolute; and those in the middle who try to combine the aspects of the two approaches (Seling, Milligan, Phibbs, \& Thompson, 2008). Adopting a relativistic approach leads to an inability to define needs (including housing needs) in a broader (global) sense, because they depend on social and cultural conditions. So, if these conditions change, needs may also change. On the other hand, an attempt can be made to identify universal needs, because as people we all have basic needs (of a lower order). According to A.H. Maslow's concept, the basic needs (at the base of the pyramid of needs) include physiological needs (food, water, protection against elements, sleep, sexual needs) and safety needs (personal, economic, health and well-being and safety i.e. protection against accidents/diseases and their consequences). Assuming that a home is a shelter, the need for a home can be easily linked to at least two of the abovementioned levels of the Maslow needs structure. In a broader context, meeting housing needs forms the basis for emotional development, conditions social participation and determines the individual status of the person (family).

This broader understanding of the importance of housing needs has been expressed by Stone (1993): „Housing is more than physical shelter. The residential environment consists of not only the dwelling unit but the site and setting, neighbours and community, municipality and public services, habitability and accessibility, rights and responsibilities, costs and benefits. Yet housing is even more than the residential environment, for it is only in relation to those who inhabit and use it that housing has meaning and significance - not only physical and economic, but emotional, symbolic and expressive"(p. 13). In this concept, housing becomes something essential and vital to the life of individuals or families and is also a means of making it easier to satisfy people's needs rather than just being an end in itself. This perception of the role of housing makes the problem of defining a housing need even more complicated. The ways of interpreting housing needs were presented in (Ytrehus, 2000).

The lack of an unambiguous or at least commonly accepted definition of this concept is an important problem in the shaping and implementing housing policy. If the policy is to respond to the housing needs of the population, it should refer to a relatively precise concept of the housing need, on the basis of which it will be possible to measure the extent of housing shortage in terms of individuals and, most of all, the society. 


\section{Housing policy}

If a dwelling satisfies the need for shelter and thus a number of other needs mentioned in the previous part of this paper and this need also has a social dimension, then in any modern country housing problems should be (or must be) the subject of social and economic policies in this respect. In general, housing policy can be considered a part of the social policy of the state, whose aim - on the basis of analysis and assessment of the housing problem (housing needs) - is to equalise social chances for obtaining housing (Salomon \& MuziołWęcławowicz, 2015). Looking at it from a narrow perspective, it is therefore one of microeconomic policies implemented by the state (on a central and local level), which involves ensuring proper functioning of the housing market. In a broader sense, housing policy is a set of state measures that affect the functioning of the housing market and its outcomes (quantity, prices and quality of housing resources) (Lis, 2011). Housing policy with a general objective of improving housing conditions in a given area (state, territorial unit) should support different social groups of citizens in meeting housing needs, with a particular focus on the needs of economically weaker groups. For this purpose, legal, institutional, organisational and financial instruments are used (Salomon \& Muzioł-Węcławowicz, 2015).

Different housing policies are in place in individual European Union states. This arises from the sovereignty of the member states in this area, cultural and political diversity and different experiences of socio-economic development during at least the period since the Second World War. This makes it extremely difficult to class countries on the basis of a similar housing policy without only taking into account very general criteria, which does not allow us to show the specific character of the policy in one country in relation to others. Therefore, below is a brief description of the housing situation and solutions introduced on the housing market over several or around a dozen years, until 2017, in selected European countries: Sweden, Germany, France, Great Britain, Spain and Poland.

A significant proportion of Sweden experiences a lack of housing mainly in metropolitan regions, the problem affects especially young people, newcomers and the elderly, who are looking for a more suitable home for their needs. Sweden has the highest housing prices in the EU and is characterised by low competitiveness in the construction sector. Due to the high housing prices, housing cooperatives and municipal housing companies have initiated projects aimed at lowering the costs of housing for the abovementioned groups of the population. Sweden generally has no social housing, but almost half of the rental sector is owned by municipal housing companies, which aim to provide housing for all, regardless of gender, age, origin or income. Rents do not differ substantially between private and public housing. The Swedish tax system favours owner-occupied housing. In 2008, the national property tax was abolished and replaced by a lower property tax. Measures were taken to regulate mortgage in order to avoid excessive indebtedness of households. In recent years, Sweden has gradually implemented a number of actions to increase the supply of new housing by removing supply bottlenecks and improving the efficiency of the housing sector: streamlining the planning and appeals process, simplifying building regulations, cutting red tape, introducing small budget support for new construction (Pittini, Koessl, Dijol, Lakatos, \& Ghekiere, 2017).

Germany is the only country in the EU where renting is more popular than owning a home. Due to the dynamic demographic development related to migration and general mobility of the population (especially young people), there is a large regional diversity in 
terms of housing: there is a lack of housing in metropolitan areas and vacancy rates are quite high in regions situated far from metropolitan areas. As a result, rents in large cities have increased significantly. In the last decade, residential construction in Germany has not been able to keep up with the growth of the population in the largest cities. Another problem is the ageing population, which means that housing stock need to be converted to meet the needs of the elderly. It is estimated that by 2035 , there will be a need for around 2.9 million of such homes. Growing rent rates force the authorities to introduce solutions for new, inexpensive residential construction, including deregulation of the housing law, prefabricated construction and stricter rent regulations (the so-called rental price brake). In Germany, there are not many typical social housing units. However, under the influence of the migration wave, more and more apartments of this type have been built in recent years (Pittini, Koessl, Dijol, Lakatos, \& Ghekiere, 2017).

The housing market in France has been gradually improving since spring of 2015, which is reflected in an increase in the number of dwellings under construction, including, to a large extent, social housing. As in Germany, the population of France concentrates around large cities, where the needs are the greatest. In order to deal with these challenges, a number of housing sector reforms have been introduced, including: reform of territorial management, rules of social housing acquisition, a new financial framework to support new social housing and a target of $25 \%$ social housing stock in France for certain regions. Great importance is also attached to the construction of social housing that meets the requirements of low-energy buildings. In 2017, the French government presented a housing policy strategy to address the lack of affordable housing. In short, it can be described in three slogans: build more, better and cheaper; respond to every need; ensure better quality of life in the neighbourhood (Pittini, Koessl, Dijol, Lakatos, \& Ghekiere, 2017).

Social housing in the UK is mainly provided by housing cooperatives and local authorities. In 2015 , such units accounted for $22 \%$ of the total number of erected dwellings. There is a persistent housing shortage in the UK, with serious adverse consequences for affordability, especially for low- and middle-income households. More than a third of all private tenants in the UK are overcharged with rent, which is also reflected in the growing homelessness figures. Over 10 years, investment in England's housing stock has fallen from an annual level of around 3 billion GBP to around 1 billion GBP (2015/16 to 2017/18). In the meantime, the number of people claiming housing benefit has increased by more than half a million. Since 2016, a co-ownership and inexpensive housing programme has been implemented. Co-ownership involves payment of rent for the unacquired part of the house. This programme places great emphasis on house ownership and does not provide any subsidies for social housing rental. In the area of social housing, perpetual rental has been abolished with the introduction of temporary contracts (up to 10 years). The programme offering the right to purchase a dwelling at a discounted rate was extended to include cooperative housing apart from social housing. Within the social welfare system there are housing benefits available for people who require support due to high maintenance costs (Pittini, Koessl, Dijol, Lakatos, \& Ghekiere, 2017).

Until 2015, Spain had to face the consequences of the housing crisis, which was reflected in a decline in the number of new homes built, a fall in prices, an increase in vacancy rates and a decrease in the availability of housing for the population. Traditionally, in Spain it is much more preferred to own a home. However, the crisis affected these preferences by increasing 
interest in housing rentals, especially among young people. Only $2.5 \%$ of households use the public rental system in Spain. The housing plan (lasting until 2017) focuses on the promotion of flats for rent, including public rental through a system of subsidies for private companies with the right to build dwellings, public authorities, foundations and associations. A programme was also established to transform empty private dwellings into cheap rental apartments. The existing housing improvement measures in Spain include: subsidised mortgage loans; rent allowances; support for evicted residents; financing the supply of housing for rent; financing of energy efficiency improvements; financing of maintenance and accessibility measures; urban and rural regeneration programme; subsidies for young people; and housing programmes and subsidies for the elderly (Pittini, Koessl, Dijol, Lakatos, \& Ghekiere, 2017).

In Poland, the number of homes per 1000 inhabitants is still one of the lowest in the EU. Successive governments over the last 20 years have introduced various programmes aimed at improving the housing situation of Polish households, but so far their effectiveness has not been high in this respect. In Poland, private ownership of a home is preferred, which is reflected in the relatively easy transformation of home ownership from cooperative to private. In recent years, the price-based availability of flats in Poland has improved. This was caused by the relative stability of prices, low interest rates on housing loans (mortgage loans) and growing salaries. On the other hand, one should not forget the limitations of this availability resulting from stricter conditions for granting mortgage loans and the problems faced by borrowers with foreign currency loans. The first government initiative to support housing construction in Poland in the 1990s for low-income households was a system of support for the supply of homes for rent with moderate rent amounts, under which Social Building Associations and the National Housing Fund were established, which was dissolved in 2009 and its tasks were taken over by Bank Gospodarstwa Krajowego. Other programmes supporting access to housing implemented in Poland include: "Rodzina na swoim" ("Family with own home"), "Mieszkanie dla młodych" ("Home for young people") and the National Housing Programme "Mieszkanie Plus" ("Home Plus"). A slightly different initiative is the Housing for Rent Fund, which was established in order to make housing rental available to people who cannot afford to pay rent at market prices or who are not creditworthy (Pittini, Koessl, Dijol, Lakatos, \& Ghekiere, 2017).

To sum up the problem of housing policy in the EU, it is worth mentioning that in June 2019 the European Commission published recommendations for member states in the field of housing policy, stressing the importance of social housing and affordable housing. Countries such as Ireland, Germany, Latvia, Luxembourg and Slovakia are affected by these problems (Housing Europe, 2019). In addition, an in-depth analysis of housing policies in selected European countries can be found in (Treanor, 2015) and about contemporary housing policy challenges is written in (UNCHSUD, 2017).

\section{MATERIAL AND METHODS}

\section{Statistical data and research method}

For the purpose of this article, data from the European Quality of Life Survey (EQLS), fourth edition, carried out by Eurofound in 2016 and 2017 in $33 \mathrm{EU}$ and other European countries, was used. The total size of the dataset was 36908 observations and the sample size for individual countries was not less than 1000. EQLS is a quality of life survey documenting 
the living conditions and social situation of the population in Europe. Housing issues are undoubtedly an important element of the standard of living and quality of life, so the questionnaire included a number of questions referring directly or indirectly to the housing conditions of the respondents and their households. For the purposes of the study on the standard of residency, three areas were distinguished: the physical characteristics of the dwelling and the financial possibilities of maintaining it (1); the quality of the neighbourhood and the environment (2); the availability of services in the vicinity of the dwelling (3). The full list of variables with their original codes is provided in Table 1.

Table 1. The list of variables with their original codes form EQLS 2016

\begin{tabular}{|c|c|c|}
\hline Variable code & Variable description & Field \\
\hline Y16_Q25a & Shortage of space & \multirow{8}{*}{$\begin{array}{l}\text { the physical } \\
\text { characteristics } \\
\text { of the dwelling } \\
\text { and the financial } \\
\text { possibilities of } \\
\text { maintaining it } \\
\text { (1) }\end{array}$} \\
\hline Y16_Q25b & Rot in windows, doors or floors & \\
\hline Y16_Q25c & Damp or leaks in walls or roof & \\
\hline Y16_Q25d & Lack of indoor flushing toilet & \\
\hline Y16_Q25e & Lack of bath or shower & \\
\hline Y16_Q25f & $\begin{array}{l}\text { Lack of facilities (heating or cooling) to keep a comfortable tem- } \\
\text { perature at home }\end{array}$ & \\
\hline Y16_Q23 & Number of rooms in accommodation / per capita & \\
\hline Y16_Q26 & Likelihood of having to leave accommodation due to affordability & \\
\hline Y16_Q54a & Neighbourhood problems: noise & \multirow{6}{*}{$\begin{array}{l}\text { the quality of } \\
\text { the neighbour- } \\
\text { hood and the } \\
\text { environment (2) }\end{array}$} \\
\hline Y16_Q54b & Neighbourhood problems: air quality & \\
\hline Y16_Q54c & Neighbourhood problems: litter or rubbish on the street & \\
\hline Y16_Q54d & Neighbourhood problems: heavy traffic & \\
\hline Y16_Q55a & I feel safe when I walk alone after dark & \\
\hline Y16_Q55b & I feel safe from crime when I am at home alone at night & \\
\hline Y16_Q56a & Access to banking facilities & \multirow{6}{*}{$\begin{array}{l}\text { the availability } \\
\text { of services in the } \\
\text { vicinity of the } \\
\text { dwelling (3) }\end{array}$} \\
\hline Y16_Q56b & Access to public transport & \\
\hline Y16_Q56c & Access to cinema, theatre or cultural centre & \\
\hline Y16_Q56d & Access to recreational or green areas & \\
\hline Y16_Q56e & Access to grocery shop or supermarket & \\
\hline Y16_Q56f & Access to recycling services & \\
\hline
\end{tabular}

Source: based on datafile from EQLS 2016.

Apart from the abovementioned variables, the EQLS data set contains one variable covering the results of the measurement on a 10-point scale of satisfaction with living conditions (variable Q6d).

The need to study complex socio-economic phenomena in a multidimensional way using synthetic measures of the level of development or e.g. poverty began to appear in the scientific literature since the 1970s. In order to assess the economic status including non-income information about the surveyed units (individuals, households and countries) in the context of inequality and social welfare, among others, wrote Kolm (1977), Atkinson and Bourguignon (1982), Maasoumi (1986), Tsui (1995; 1999), Weymark (2006), Aristei and Bracalente (2011). In some cases, the authors combined different indicators in order to obtain a multidimensional index of standard of living, economic status or poverty. For example, Anand and Sen (1997) described the possibilities of using the synthetic index of human poverty at the macro level for various systems of weights of partial indexes. 
Whereas at micro level Smeedeing et al. (1993) studied effect of non-cash income (education, health and housing) among others on living standard.

In order to make a comprehensive statistical comparative analysis of the objects (countries) due to complex phenomena, methods of linear ordering and hierarchical clustering are used in this work. The former facilitates projection of points representing countries placed in a multidimensional space of variables on a straight line. This in turn makes it possible to establish the position of a given country in the hierarchy of countries based on the studied phenomenon (housing situation). Among the methods of linear ordering we can distinguish methods based on synthetic variables, whose general idea boils down to aggregation of a set of variables describing objects in a multidimensional system. This approach is widely used in the study of complex socio-economic phenomena, such as levels of development, prosperity, poverty, etc. In the case of hierarchical clustering methods, the key result is the ability to associate a given object with a larger number of other objects without defining the order of these objects. This connection leads to the consequent grouping of these objects. Both methodological approaches will be used for further consideration.

In order to aggregate information from different variables, it is necessary to standardise the variables. Of the many possibilities, the zero-unitary method is frequently used, where primary variables are normalized according to the formula:

where:

$$
z_{i j}=\frac{x_{i j}-\min _{\mathrm{i}}\left\{x_{i j}\right\}}{\max _{i}\left\{x_{i j}\right\}-\min _{i}\left\{x_{i j}\right\}}
$$

$x_{i j}$ - denotes the value of the $j$-th variable for the $i$-th object.

The formula above is applied to variables that are developmental stimuli measured on at least an interval scale. Due to the fact that the objects are states, in the case of dichotomous variables, the value of such a variable $\left(x_{i j}\right)$ for a given country is the share of responses given by those respondents who assess housing conditions as good among all respondents. For example, variable Q25a (too little space in the home) has two categories: yes, no. On the basis of this variable, the proportion of "no" answers is calculated for each country and becomes a variable $\left(x_{i j}\right)$, describing one of the dimensions of the housing conditions. The higher the share, the better the housing situation in the country. In this way, all such variables are stimulants of housing conditions. Where a primary variable is characterised by more than two categories, the conversion should be slightly different. First, we determine the share of the respondents' responses for each category of the variable. Then we apply the formula for obtaining one value (for a given country) for the $x_{i j}$ variable:

where:

$$
x_{i j}=\frac{\sum_{s=0}^{S-1} s * w_{i j s}}{S-1}
$$

$w_{i j s}$ - is the share of respondents who chose the s-th category of response to the problem from the original $j$-th variable (order variable with s categories) for the $i$-th country.

Of course, the order of these categories must reflect increasing improvement in housing conditions. The result is in the range from 0 to 1 , where 0 indicates a situation where all the respondents in the country would indicate the worst housing situation with regard to the 
variable under consideration and 1 is the opposite. Values of the variable $x_{i j}$ obtained according to the formula (2) are not interpretable but make it possible to assess and compare the housing situation in the countries surveyed at the level of the $j$-th variable.

After application of formula (1) for variables $x_{i j}$ a weighted average was calculated for the three areas. The weighing system was selected based on the proposal of Betti and Verma (1999). It takes into account the discriminatory and information capacity of variables. Discriminatory ability are most often assessed by measuring the variation level of the variable, while the information capacity is measured on the basis of the level of the given variable's correlation with all the other variables. The said system of weights can thus be expressed as follows:

where:

$$
w_{h j}=w_{h j}^{a} \cdot w_{h j}^{b}, h=1,2, \ldots, m ; j=1,2, \ldots, k_{h}
$$

$\mathrm{w}_{\mathrm{hj}}^{\mathrm{a}}$ - is the measure of the information level of the $j$-th variable in the $h$-th field;

$w_{h j}^{b}$ - is the measure of the discriminatory capacity of the $j$-th variable in the $h$-th field.

Defining weights based on individual correlated variables is performed to favor most of these variables that are at least correlated with some other variables, and vice versa, the least rewarded are those with the highest correlation. Applying the following formula implements this requirement:

$$
w_{h j}^{a}=\left[\frac{1}{1+\sum_{j^{\prime}=1}^{k_{h}}\left|r_{z_{h j, h j^{\prime}}}\right| \mid r_{z_{h j, h j^{\prime}}}<r_{z_{h j}}^{*}}\right]\left[\begin{array}{c}
\frac{1}{\sum_{j^{\prime}=1}^{k_{h}}\left|r_{z_{h j, h j^{\prime}} \mid}\right| r_{z h j, h j^{\prime}} \geq r_{z_{h j}}^{*}} \\
j, j^{\prime}=1,2, \ldots, k_{h} ; h=1,2, \ldots, m
\end{array}\right.
$$

where:

$r_{z h, h j^{\prime}}$ - is the correlation coefficient of housing standard corresponding to $j$-th and $j$-th variable in the $h$-th field;

$r_{z h j}^{*}$ - is the threshold value of the correlation coefficient of housing standard due to the $j$-th variable in the $h$-th field that can be evaluated as follows:

$$
r_{z h j}^{*}=\min _{j} \max _{j \prime}\left|r_{z_{h j, h j}}\right|, j, j^{\prime}=1,2, \ldots, k_{h j} ; \neq j^{\prime} .
$$

After calculating the weighted average for each country and area, the overall synthetic variable was calculated as the arithmetic mean of the area averages.

The procedure presented above allowed for linear ordering of the surveyed countries due to their standard of living, while in the case of hierarchical clustering, Ward agglomeration procedure with the use of Euclidean distance was used. In the case of linear ordering of countries, the division of objects (countries) into classes can be done according to the following formula:

$$
\text { (1) } G_{1}: s_{i}<\bar{s}-S(s)
$$

(2) $G_{2}: \bar{s}>s_{i} \geq \bar{s}-S(s)$

(3) $G_{3}: \bar{s}+S(s)>s_{i} \geq \bar{s}$

where:

$$
\text { (4) } G_{4}: s_{i} \geq \bar{s}+S(s) \text {, }
$$

$\bar{S}$ - arithmetic mean of the synthetic variable;

$S(s)$ - Standard deviation of the synthetic variable. 


\section{Empirical results}

First of all, the results of the structure of the responses to the question of satisfaction with accommodation are presented. Figure 1 presents the results of this structure for selected EU countries.

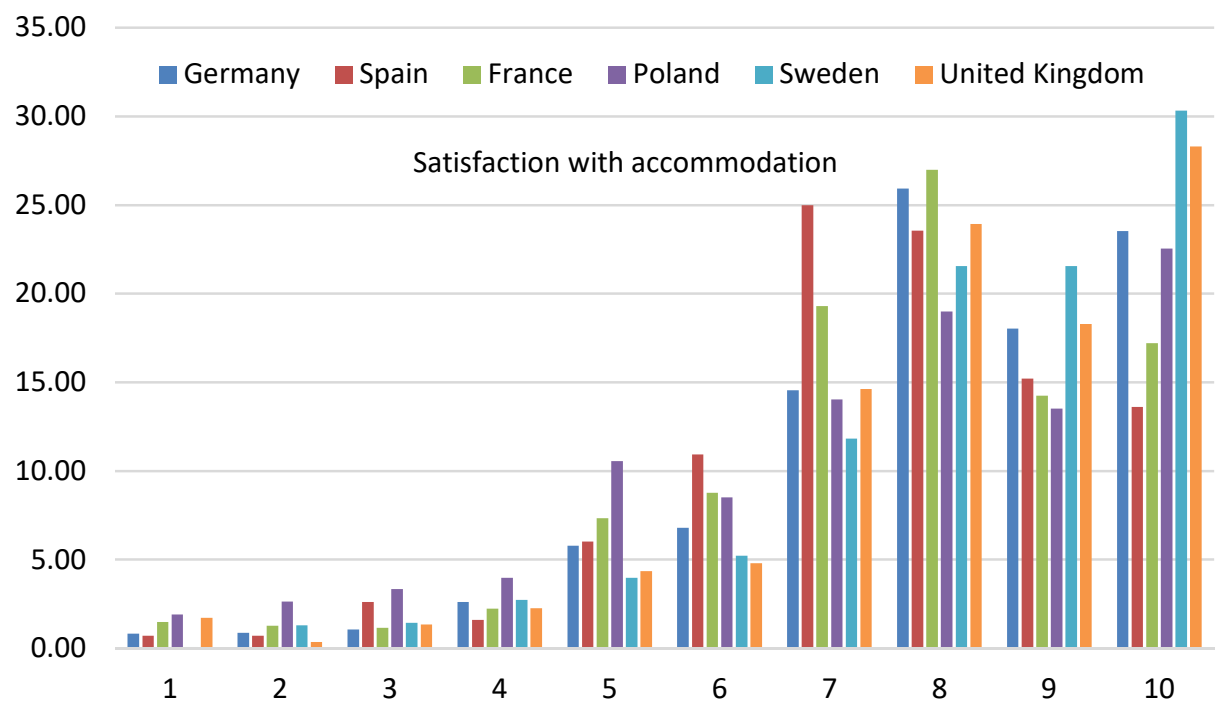

Figure 1. Satisfaction with accommodation - measurement for selected EU countries Source: own calculations based on data from EQLS 2016.

In general, in all the countries presented, the respondents most often express a high level of satisfaction with their place of residency. The dominant rating for Great Britain, Poland and Sweden is 10 (very satisfied), while for France and Germany it is 8 and for Spain it is 7 . It is also worth noting that low ratings for satisfaction with residency conditions (lower than 6) were the most common in Poland, which suggests a relatively large variation in satisfaction in Poland in relation to the countries presented. Taking into account the other countries (apart from the countries presented in the chart), a low level of satisfaction was observed the most often in Albania and the highest - in Austria and Denmark.

Another frequently used indicator of the housing situation (standard of living) is the number of rooms per person living in the housing unit. Figure 2 shows the values of this indicator for the European countries surveyed, highlighting selected EU countries. By far the worst housing situation is in the Balkans. Poland is also characterised by a relatively low number of rooms per capita (1.15) and is far behind from the other 5 countries, with the best situation in the UK. Among all the countries surveyed with EQLS, Belgium had the highest number of rooms per capita (2.25) and Albania the lowest (0.65).

It is worth noting that the countries differ significantly due to the adopted measure of the standard of living. The gap between Belgium and Albania points to a generally worse housing situation for the population in Albania in both relative and absolute terms. In addition, it can also be seen that on the left-hand side of figure 2 (with lower 
values) are mainly post-socialist countries, while on the right-hand side are western European countries. This shows that despite various problems in the housing market in the latter group of countries, the citizens of these countries are still in a better housing situation than the population of Eastern European countries, even after 25 years since the beginning of the systemic transformation in the region.

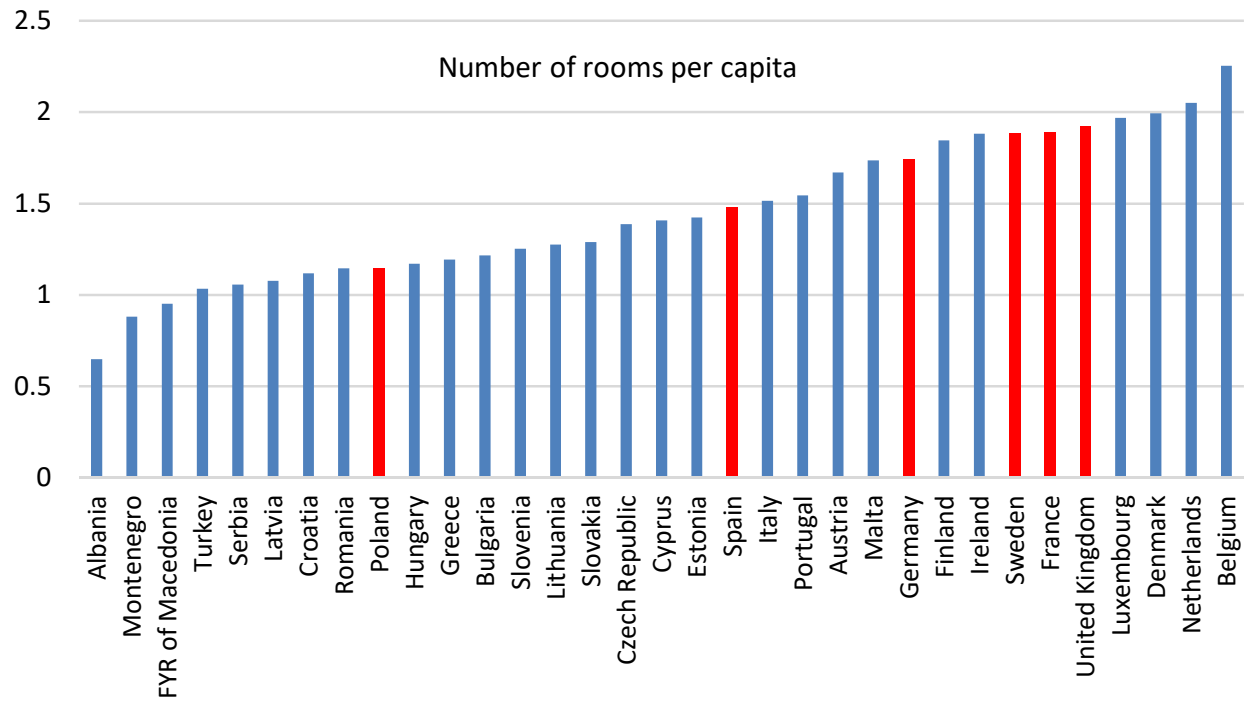

Figure 2. Number of rooms per person in European countries Source: own calculations based on data from EQLS 2016.

Table 2 summarises the results of the comprehensive assessment of the standard of residency in the examined European countries. The first part of the table presents the synthetic value of the measure of the standard of residency in the first area - the physical characteristics of the home and its maintenance, the second area - the quality of the neighbourhood and surroundings, the third area - the availability of services in the surroundings of the home and in the overall system. In the second part of the table, the rankings of the surveyed European countries are similarly presented based on the standard of residency of the population.

In general, no country has obtained the highest score for the standard of residency in all areas. The closest to achieving this was the Netherlands, which was ranked first in two areas: first and third, as in terms of the overall evaluation. Sweden achieved evenly high ratings for the standard of residency. Whereas Turkey, Albania and Montenegro have the lowest ratings for housing standards.

Taking into account the highlighted countries (France, Germany, Spain, Sweden, Great Britain and Poland), it is worth noting that Poland does not differ much from most of them. Only Sweden is the undisputed leader in the hierarchy of countries based on their standard of residency. This result differs positively from the assessment of Poland's housing situation made on the basis of commonly used indicators, such as the one presented in Figure 2. This shows that it is worth looking at the assessment of housing conditions (housing standard) from a multidimensional perspective for greater accuracy, because this standard is a multidimensional phenomenon. 
Table 2. Values of a synthetic measure of the standard of residency and ranking of countries due to the standard of residency

\begin{tabular}{|c|c|c|c|c|c|c|c|c|}
\hline \multirow{2}{*}{ Country } & \multicolumn{4}{|c|}{ Synthetic measure } & \multicolumn{4}{|c|}{ Ranking } \\
\hline & Field 1 & Field 2 & Field 3 & Total & Field 1 & Field 2 & Field 3 & Total \\
\hline Albania & 0.524 & 0.483 & 0.366 & 0.458 & 32 & 23 & 26 & 31 \\
\hline Austria & 0.876 & 0.692 & 0.694 & 0.754 & 3 & 11 & 10 & 5 \\
\hline Belgium & 0.742 & 0.395 & 0.481 & 0.539 & 14 & 27 & 22 & 24 \\
\hline Bulgaria & 0.718 & 0.288 & 0.686 & 0.564 & 19 & 32 & 11 & 23 \\
\hline Croatia & 0.704 & 0.531 & 0.260 & 0.498 & 21 & 20 & 30 & 26 \\
\hline Cyprus & 0.730 & 0.545 & 0.925 & 0.734 & 17 & 18 & 2 & 8 \\
\hline Czech Republic & 0.738 & 0.363 & 0.594 & 0.565 & 15 & 29 & 17 & 22 \\
\hline Denmark & 0.832 & 0.879 & 0.877 & 0.863 & 8 & 2 & 4 & 2 \\
\hline Estonia & 0.708 & 0.741 & 0.603 & 0.684 & 20 & 8 & 16 & 11 \\
\hline Finland & 0.885 & 0.985 & 0.533 & 0.801 & 2 & 1 & 19 & 4 \\
\hline France & 0.696 & 0.700 & 0.371 & 0.589 & 23 & 9 & 25 & 20 \\
\hline FYR of Macedonia & 0.643 & 0.396 & 0.412 & 0.484 & 28 & 26 & 24 & 28 \\
\hline Germany & 0.876 & 0.514 & 0.629 & 0.673 & 4 & 21 & 14 & 13 \\
\hline Greece & 0.652 & 0.351 & 0.746 & 0.583 & 27 & 30 & 8 & 21 \\
\hline Hungary & 0.738 & 0.694 & 0.415 & 0.615 & 16 & 10 & 23 & 18 \\
\hline Ireland & 0.826 & 0.794 & 0.612 & 0.744 & 10 & 5 & 15 & 7 \\
\hline Italy & 0.730 & 0.383 & 0.299 & 0.471 & 18 & 28 & 29 & 30 \\
\hline Latvia & 0.604 & 0.667 & 0.721 & 0.664 & 30 & 14 & 9 & 15 \\
\hline Lithuania & 0.655 & 0.563 & 0.779 & 0.666 & 26 & 16 & 5 & 14 \\
\hline Luxembourg & 0.817 & 0.667 & 0.749 & 0.744 & 11 & 13 & 7 & 6 \\
\hline Malta & 0.842 & 0.301 & 0.634 & 0.592 & 6 & 31 & 13 & 19 \\
\hline Montenegro & 0.631 & 0.439 & 0.202 & 0.424 & 29 & 25 & 31 & 32 \\
\hline Netherlands & 0.941 & 0.784 & 0.945 & 0.890 & 1 & 6 & 1 & 1 \\
\hline Poland & 0.753 & 0.680 & 0.510 & 0.648 & 13 & 12 & 21 & 16 \\
\hline Portugal & 0.702 & 0.751 & 0.154 & 0.536 & 22 & 7 & 33 & 25 \\
\hline Romania & 0.580 & 0.509 & 0.354 & 0.481 & 31 & 22 & 28 & 29 \\
\hline Serbia & 0.658 & 0.469 & 0.365 & 0.497 & 25 & 24 & 27 & 27 \\
\hline Slovakia & 0.840 & 0.541 & 0.645 & 0.676 & 7 & 19 & 12 & 12 \\
\hline Slovenia & 0.800 & 0.807 & 0.556 & 0.721 & 12 & 4 & 18 & 9 \\
\hline Spain & 0.688 & 0.656 & 0.531 & 0.625 & 24 & 15 & 20 & 17 \\
\hline Sweden & 0.859 & 0.838 & 0.890 & 0.862 & 5 & 3 & 3 & 3 \\
\hline Turkey & 0.272 & 0.125 & 0.157 & 0.185 & 33 & 33 & 32 & 33 \\
\hline United Kingdom & 0.827 & 0.551 & 0.758 & 0.712 & 9 & 17 & 6 & 10 \\
\hline
\end{tabular}

Source: own calculations based on data from EQLS 2016.

Figure 3 presents the division of European countries into four groups, based on the standard of residency in three areas and the overall assessment of this standard. The division was made using formula (5).

Figure 3 graphically confirms the previous conclusions. Looking at Poland, we can see that in areas 1 and 2 it falls in the third group (in the hierarchy of groups 1 to 4). Finally, based on the general assessment of the standard of residency, Poland can also be included in the third group of countries. It is also worth noting that the standard of residency in Italy was poorly rated, which is also confirmed by the results in Table 2. 


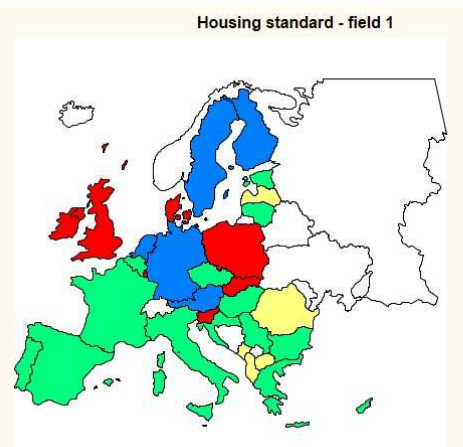

Housing standard - field 3

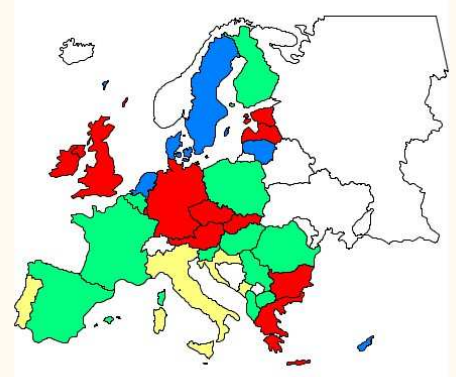

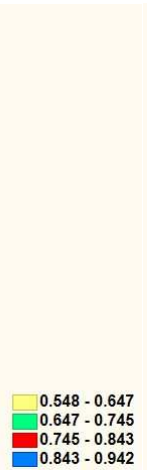

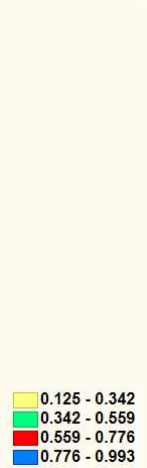

Housing standard - field 2

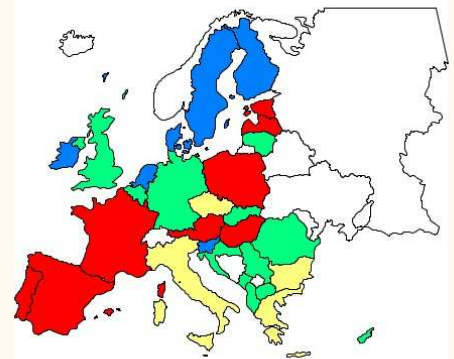

Housing standard - total

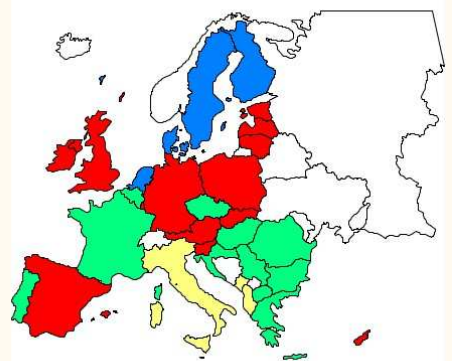

Figure 3. Division of European countries by standard of residency based on area and overall assessment - linear ordering Source: own calculations based on data from EQLS 2016.

In principle, the classification of countries in Figure 4 also confirms previous conclusions. However, it is worth remembering that tree diagrams are the result of applying clustering of objects, i.e. they provide information about the similarity of individual countries and not about their ordering. In interpreting the composition of the groups, an attempt may be made to assign them a level of residency standard and to establish a hierarchy, although this is not the primary objective of clustering.

Taking into account Poland in the arrangement of all variables, it fell in the same group as Spain, then as France and then as Austria, Ireland, Slovenia and Finland. Analysing the classification of countries based on the three synthetic variables, Poland shows similarities to Spain, then Estonia and then to France and Hungary.

\section{CONCLUSIONS}

Undoubtedly, the issue of housing and social and economic policy in this area is an important and still topical research and practical issue. The question of how to shape the housing policy (in social and economic terms) in order to increase the level of satisfaction of the housing need, both in terms of quantity and quality, is still relevant. Unfortunately, there is no easy and unambiguous answer to this question. An overview of policies in EU 


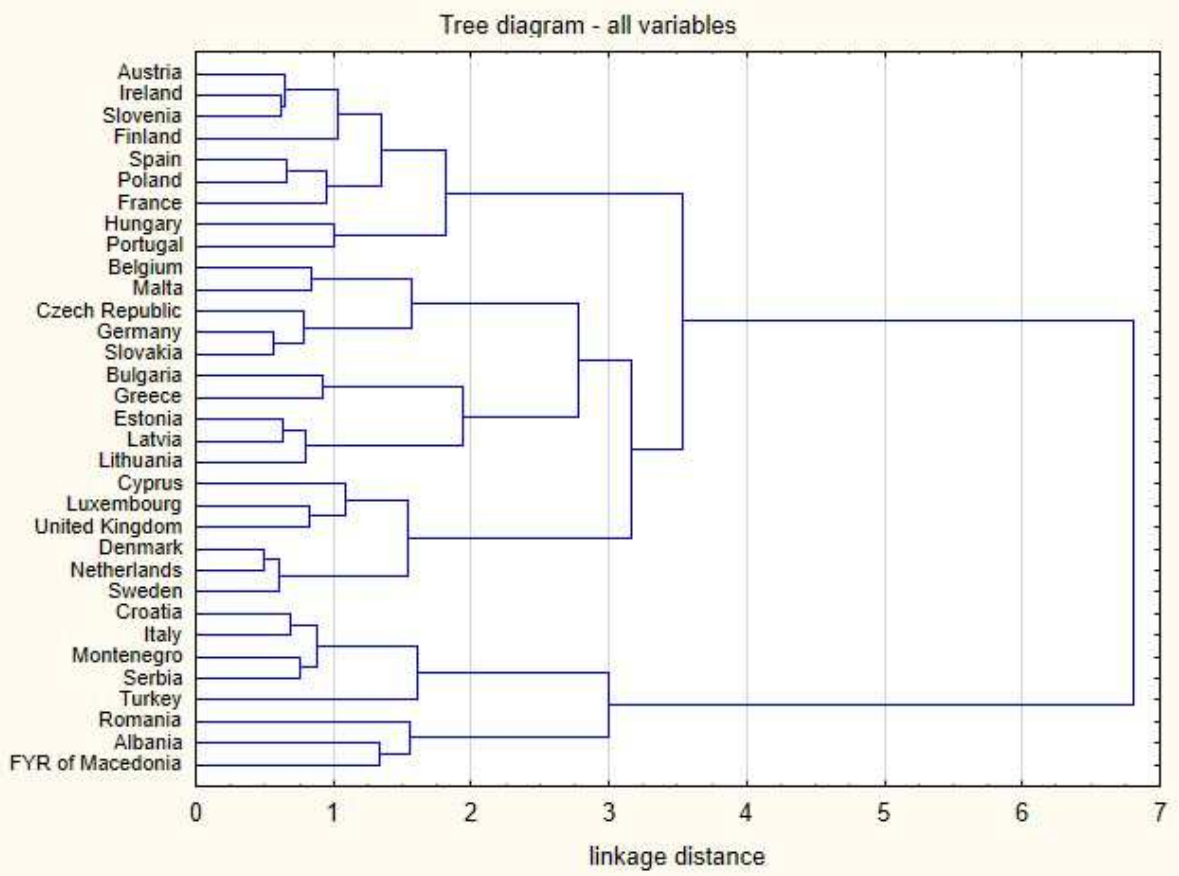

Tree diagram - synthetic variables

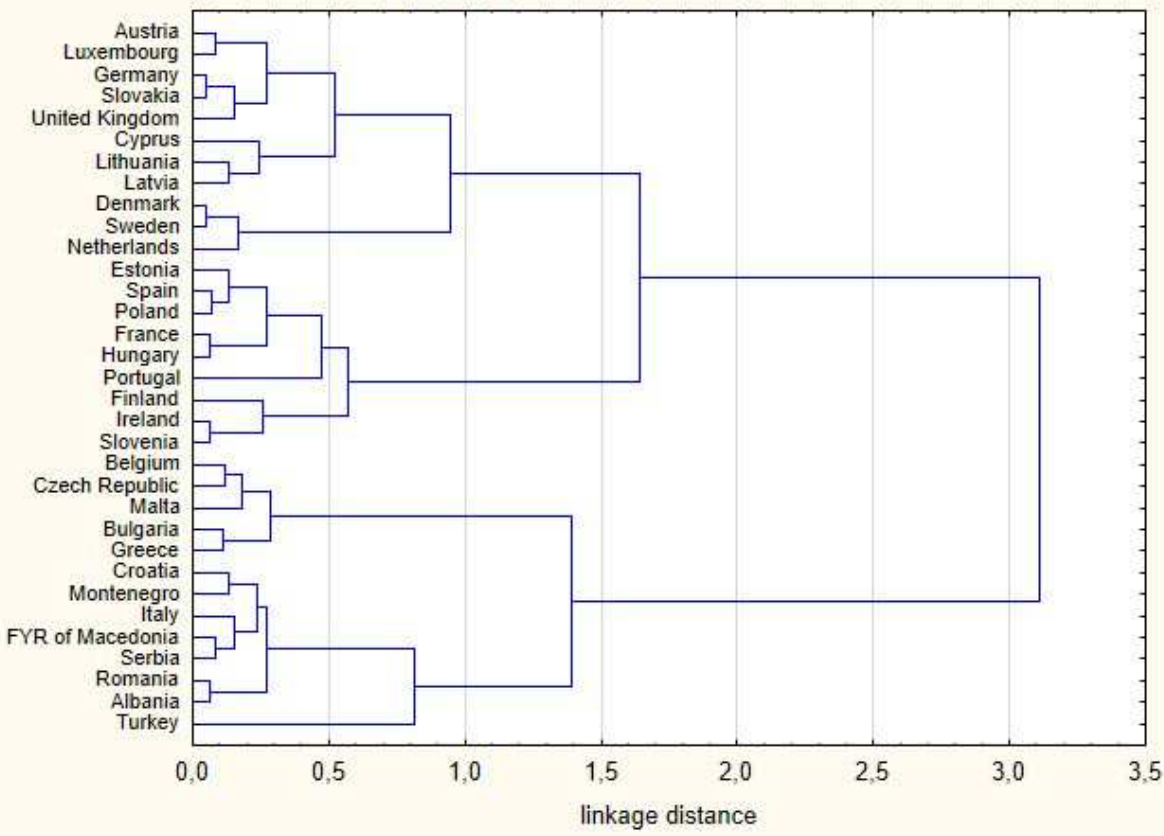

Figure 4. Division of European countries by standard of residency based on area and overall assessment - hierarchical clustering

Source: own calculations based on data from EQLS 2016. 
countries shows that the solutions to the "housing problem" are sometimes very different and often linked to the financial capacity of the country over a given period of time. It is therefore difficult to compare the effectiveness of this policy in terms of specific solutions, which does not prevent final (overall) comparisons of its outcomes. It should also be remembered that these effects are the result of a number of more long-term and well thought-out as well as short-term and timely actions, which means that housing policy and its current effects should be viewed in the long term.

The results presented in the paper show - obviously, not in the full scope - the effects of housing policy in European countries, although it is worth remembering that the standard of residency is not just the result sensu stricto of the state housing policy. These results were based on a multidimensional approach to the assessment of the standard of residency. It undoubtedly has advantages over the use of single and numerically limited indicators of the housing situation. The advantage is that as much information as possible on this situation, covering both its quantitative and qualitative aspects, is taken into account. However, the problem is access to comparable data, access to data containing relevant information on the housing situation (relevant indicators) and methodological solutions concerning the construction of a synthetic variable and grouping of the countries surveyed. The researcher has to decide on the manner of aggregation of individual indicators (their selection, standardization, weighting, aggregation formula) and on the number of groups of countries or the threshold for their differentiation. Nevertheless, it seems that this approach sheds a different (perhaps new) light on the housing situation - here in terms of the standard of residency - in comparative research. The evidence is a much better assessment of the situation in Poland in relation to other countries than the one made on the basis of an index relating to the number of apartments or the number of rooms per specified number of persons.

Moreover, having individual data allows further research to monitor the standard of residency of social groups distinguished on the basis of specific socio-economic characteristics, which in turn will allow for comparison of the housing situation of these groups, both within a given country and between countries. To this end, it is possible to use, for example, a multidimensional approach to measuring the quality of housing based on the fuzzy set theory, widely used in research on the assessment of poverty risk.

\section{REFERENCES}

Anand, S., \& Sen, A. (1997). Concepts of human development and poverty: a multidimensional perspective. New York: United Nations Development Programme.

Aristei, D., \& Bracalente, B. (2011). Measuring multidimensional inequality and well-being: Methods and Empirical Applications to Italian Regions. Statistica, LXXI (2), 239-266.

Atkinson, A.B., \& Bourguignon, F. (1982). The comparison of multi-dimensional distributions of economic status. Review of Economic Studies, XLIX, 183-201.

Betti, G., \& Verma, V. (1999). Measuring the degree of poverty in a dynamic and comparative context: A multi-dimensional approach using fuzzy set theory. In Proceedings from ICCS-VI: The Sixth Islamic Countries Conference on Statistical Sciences, 11, 289-301.

Fordham, R., Finlay, S., Gardner, J., Macmillan, A., Muldoon, C., Taylor, G., \& Welch, G. (2018). Housing need and the need for housing. New York: Routledge. 
Housing Europe (2019). A stronger focus on affordable and social housing in the 2019 CSRs. A housing Europe Analysis. Retrieved from http://www.housingeurope.eu/resource-1303/a-stronger-focus-on-affordable-and-social-housing-in-the-2019-csrs.

Kolm, S.C. (1977). Multidimensional egalitarianism. Quarterly Journal of Economics, 91, 1-13.

Kwarciński, T., \& Ulman, P. (2018). A hybrid version of well-being: an attempt at operationalization. Zarzqdzanie Publiczne, 4 (46), 30-49. DOI 10.15678/ZP.2018.46.4.03

Lis, P. (2011). Cele i instrumenty społecznej polityki mieszkaniowej. In: J. Dzieciuchowicz (Ed.), Współczesne przemiany środowiska mieszkaniowego - wybrane problemy (9-28). Łódź: Wydawnictwo Uniwersytetu Łódzkiego.

Maasoumi, E. (1986). The measurement and decomposition of Multidimensional Inequality. Econometrica, 54, 771-779.

Pittini, A., Koessl, G., Dijol, J., Lakatos, E., \& Ghekiere, L. (2017). The state of housing in the EU 2017. A Housing Europe Review. Brussels: The European Federation of Public, Cooperative and Social Housing.

Salomon, M., \& Muzioł-Węcławowicz, A. (Eds.) (2015). Mieszkalnictwo w Polsce. Analiza wybranych obszarów polityki mieszkaniowej. Warszawa: Habitat for Humanity Poland.

Seling, T., Milligan, V., Phibbs, P., \& Thompson, A. (2008). Reconceptualizing housing need in the context of $21^{\text {st }}$ century Australian housing policy. AHURI Positioning Paper, 110.

Smeeding, T., Saunders, P., Coder, J., Jenkins, S.P., Fritzell, J., Hagenaars, A., Hauser, R., \& Wolfson M. (1993). Poverty, inequality and family living standards impacts across seven nations: The effect of non-cash subsidies for health, education and housing. Review of Income and Wealth, 39, 229-256.

Soltes, E., \& Ulman, P. (2015). The monetary and non-monetary aspects of poverty in Poland and Slovakia. Entrepreneurial Business and Economics Review 3 (1), 61-73. https://doi.org/10.15678/EBER.2015.030105

Stone, M.E. (1993). Human needs and housing affordability. In: M.E. Stone, Shelter poverty: New ideas on housing affordability (13-31). Philadelphia: Temple University Press.

Treanor, D. (2015). Housing polices in Europe. M3 Housing Ltd.

Tsui, K.Y. (1995). Multidimensional generalizations of the relative and absolute inequality indices: The Atkinson-Kolm-Sen approach. Journal of Economic Theory, 67, 251-265.

Tsui, K.Y. (1999). Multidimensional inequality and multidimensional generalized entropy measure: an axiomatic derivation. Social Choice and Welfare, 16, 145-157.

UNCHSUD (2017). Habitat III Policy Papers: Policy Paper 10 Housing Policies. New York: United Nations - United Nations Conference on Housing and Sustainable Urban Development.

Weymark, J.A. (2006). The Normative approach to the measurement of multidimensional inequality. In: F. Farina, E. Savaglio (Eds.), Inequality and economic integration (303-328). London: Routledge.

Wiśniewski, A., \& Śleszyński, D. (1976). Koncepcja hierarchicznej struktury potrzeb w teorii Abrahama H. Maslowa. Studia Philosophiae Christianae, 12(2), 191-199.

Wójciaczyk, W. (2016). Analiza porównawcza sytuacji mieszkaniowej w wybranych krajach Unii Europejskiej. Zeszyty Naukowe Uniwersytetu Ekonomicznego w Krakowie 3(951), 81-98. DOI: 10.15678/ZNUEK.2016.0951.0306

Ytrehus, S. (2000). Interpretation of housing needs? A critical discussion. Housing, Theory and Society, 17(4), 166-174. DOI: 10.1080/140360900300108591 


\section{Author}

\section{Paweł Ulman}

Associate Professor of Cracow University of Economics. His research interests include social statistics: income distribution, poverty, well-being, quality of life, economic discrimination, economic activity. Correspondence to: Prof. Paweł Ulman PhD, Cracow University of Economics, Department of Statistics, ul. Rakowicka 27, 31-510 Krakow, Poland, e-mail: ulmanp@uek.krakow.pl ORCID (1) http://orcid.org/0000-0002-1911-8821

\section{Acknowledgements and Financial Disclosure}

The publication was funded by appropriations of the Faculty of Management at the University of Economics in Krakow, as a grant to maintain the research capacity.

\section{Copyright and License}

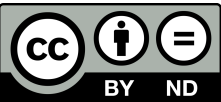

This article is published under the terms of the Creative Commons

Attribution - NoDerivs (CC BY-ND 4.0) License

http://creativecommons.org/licenses/by-nd/4.0/

\section{Published by the Centre for Strategic and International Entrepreneurship - Krakow, Poland}

The journal is co-financed in the years $2019-2020$ by the Ministry of Science and Higher Education of the Republic of Poland in the framework of ministerial programme "Support for Scientific Journals" (WCN) on the basis of contract no. 238/WCN/2019/1 concluded on 15 August 2019. 
